9. Помиткін Е. О. Психологія духовного розвитку особистості : [монографія] / Е. О. Помиткін. - К. : Наш час, 2005. - 280 c.

10. Практична педагогіка виховання : посіб. 3 теорії та методики виховання / за заг. ред. М. Ю. Красовицького, упор. Г. І. Іванюк. - К. = Івано-Франківськ : Плай, 2000. - 143 с.

11. Стельмахович М. Г. Українська народна педагогіка : навч.-метод. посіб. / М. Г. Стельмахович. -К. : I3MH, 1997. - $232 \mathrm{c}$.

12. Тимощук Н. С. Особистісно орієнтоване виховання старшокласників у процесі позакласної ро- боти : навч.-метод. посіб. / Н. С. Тимощук. - Рівне : Волинські обереги, 2004. - 281 с.

13. Ушинський К. Д. Людина як предмет виховання: спроба педагогічної антропології / К. Д. Ушинський // Твори : в 6 т. - К. : Рад школа, 1952. - Т. 4. $528 \mathrm{c}$.

14. Шмигіна Н. Соціальне середовище та формування особистості учня / Н. Шмигіна // Студент-2 : зб. наук. пр. ; за ред. М. Ф. Бойка. - Херсон : Айлант, 1999. $-68 \mathrm{c}$.

Дата надходження до редакиї: 18.02 .2020 р.
УДК 37.01

DOI: 10.37026/2520-6427-2020-102-2-150-153
Світлана КИРИЛЕНКО,

кандидат педагогічних наук, начальник відділу інноваџійної діяльності та дослідно-експериментальної роботи ДНУ «Інститут модернізації змісту освіти», м. Київ

\title{
УЧИТЕЛЬ ЯК НОСІЙ ЦІННОСТЕЙ ВИХОВАННЯ В СУЧАСНОМУ ЗАКЛАДІ ЗАГАЛЬНОЇ СЕРЕДНЬОЇ ОСВІТИ
}

У статті визначено мету професійної діяльності вчителя як вихователя $i$ носія иінностей $y$ сучасних закладах загальної середньої освіти, його прагнення до самовдосконалення, вивчення кращого педагогічного досвіду, інновачій в освіті, комунікачіі зі своїми колегами, активна громадянська позиція, патріотизм. Розглянуто умови для всебічного гармонійного розвитку особистості учня, його самореалізачії, розкриття індивідуальності, творчого потениіалу. Закиентовано увагу на превентивних заходах у роботі з дітьми, щзо визначаються приділенням особливої уваги формуванню ідентичності, основ духовності особистості, культури мислення $і$ культури поведінки, профілактиці шкідливих звичок, ризикованої девіантної поведінки, жорстокості $і$ насилля $в$ учнівському середовищі.

Ключові слова: сучасний учитель, парадигма виховання, різновекторність виховних впливів, морально-етичні иінності, гармонійний розвиток особистості учня, творчий потенціал педагога.

В статье определень иели профессиональной деятельности учителя как воспитателя и носителя ценностей в современных учреждениях общего среднего образования, его стремление к самосовершенствованию, изучение лучшего педагогического опьыта, инноваций в образовании, ком- муникации со своими коллегами, активная гражданская позиция, патриотизм. Рассмотрено условия для всестороннего гармоничного развития личности ученика, его самореализаџии, раскрытия индивидуальности, творческого потенциала. Обрамено внимание на превентивные меры в работе с детьми, что определяются уделением особого внимания формированию идентичности, основ духовности личности, культуры мылиления и культуры поведения, профилактике вредных привычек, рискованного девиантного поведения, жестокости и насилия в ученической среде.

Ключевые слова: современный учитель, парадигма воспитания, разновекторность воспитательных воздействий, морально-этические иенности, гармоничное развитие личности ученика, творческий потенцииал педагога.

The purpose of professional activity of teacher as educator and carrier of values in modern institutions of general secondary education is defined in the article; striving for self-improvement, teaching of advanced pedagogical experience, communication with colleagues, active civic position, patriotism; the conditions for comprehensive harmonious development of the student's personality, his / her self-realization, revealing of individuality, creative potential are revealed. Attention is paid 
to preventive measures in work with children, which are determined by paying special attention to identity formation, the foundations of personality spirituality, culture of thinking and culture of behavior, prevention of bad habits, risky deviant behavior, cruelty and violence in the student environment.

Complexity of modern educational problems requires a comprehensive approach in their solution and development of social and pedagogical paradigm of education. The basis of the new paradigm, and therefore the basis of education are the personality of the child, recognition of its highest value, the orientation of the teacher on humane, democratic principles in common with the child life, so the generation of a strategy of subject-subjective interaction. Therefore, the purpose of the professional activity of the teacher as educator and bearer of values is to create the conditions for a comprehensive harmonious development of the student's personality, his self-realization, the disclosure of individuality, creative potential.

The talent of the teacher, the teacher is manifested in his bright abilities of the organizer, able to communicate, persuade, think logically, able to possess himself, the desire for new knowledge and erudition, interest in innovative pedagogical ideas.

Key words: modern teacher, paradigm of upbringing, heterogeneity of educational influences, moral and ethical values, harmonious development of student personality, teacher's creative potential.

Постановка проблеми. У закладі загальної середньої освіти все починається 3 учителя. I хоча результати навчання і виховання учнів залежать від трьох основних чинників - хто навчає, кого навчають та як навчають, - важко сказати, що з усього цього найважливіше. Безумовно, ключовою у справі виховання є роль учителя, його особистості.

Так уже склалося, що образ сучасного вчителя передусім пов'язують із його місією бути менеджером-організатором освітнього процесу. У такій системі освітнього простору виховний потенціал навчання дещо нівелюється, вважається другорядним, надаючи пріоритет виключно одержанню знань, які у майбутньому допоможуть молодій людині у побудові успішної кар'єри.

Аналіз наукових досліджень і публікацій. Метою професійної діяльності педагога $є$ створення умов для гармонійного розвитку особистості учня, його самореалізації, розкриття індивідуальності, творчого потенціалу. Вчитель має усвідомлювати унікальність і неповторність учня як індивідуальності, зважати на складність та неоднозначність процесу його становлення, а також свою відповідальність як професіонала. Однак сьогодні змінилися вимоги не лише до вчителя, а й до учня. У працях В. Андрущенка, I. Беха, А. Бойко, В. Галузинського, С. Гончаренка, Р. Гуревича, Ю. Завалевського, О. Киричук, Г. Костюка, В. Кременя, М. Лещенко, В. Моляко, Н. Ничкало, О. Отич, І. Підласого, В. Рибалки, О. Романовського, О. Рудницької, С. Сисоєвої, О. Семеног, М. Солдатенка, М. Фіцули та інших проблему розвитку та становлення сучасного вчителя, вихователя розглянуто в різноманітних аспектах.
Мета статті - визначити професійну діяльність учителя як вихователя і носія цінностей, його прагнення до самовдосконалення, інновацій в освіті.

Виклад основного матеріалу. Становлення і розвиток громадянського суспільства зумовлює гостру необхідність у педагогах, які володіють високою професійною компетентністю. Отже, сучасний учитель - це не лише предметник, а й знавець дитячих душ, вихователь. Зрозуміти світ дитини дуже складно, вона потребує допомоги дорослих. При цьому допомогти може тільки той, хто сам достатньою мірою володіє знаннями про цей новий світ, приймає все нове і сам здатний змінитися. Такою особистістю є вчитель. Який же він - сучасний учитель нової української школи?

На нашу думку, сучасний учитель як носій цінностей характеризується вірністю гуманістичним i демократичним цінностям, повагою до дітей, умінням навчати й спрямовувати дитячий колектив на добрі й важливі справи, прагненням до самовдосконалення, вивчення кращого педагогічного досвіду, інновацій в освіті, комунікацією зі своїми колегами, активною громадянською позицією, патріотизмом, причому є прикладом у повсякденності (у побуті, культурі поведінки, в ставленні до оточуючого світу, рідних, близьких, друзів, колег).

Думка про провідну роль особистості педагога як вихователя і носія цінностей у сучасній школі більшою мірою стосується його моральних якостей. Кожен педагог незалежно від фаху є вихователем. Він виховує дітей не лише змістом свого навчального предмета, але й ставленням до справи, власним світоглядом, манерами поведінки і навіть зовнішністю. Сучасний учитель - це творча особистість. Він має бути активним, комунікабельним, динамічним, працездатним, вольовим, упевненим у собі, толерантним, висококомпетентним.

Учні дивляться на педагога як на професіонала виховання, який, навчаючи інших, сам має бути близьким до взірця культурної, вихованої людини. Кожна позитивна риса особистості педагога (справедливість, ерудованість, доброзичливість, почуття гумору) підмічається учнями і викликає бажання іii наслідувати. Привабливий, популярний педагог навіть без спеціального наміру передає учням певні якості власної особистості. Однак водночас так само швидко та безпомилково діти помічають такі вади, як недоброзичливість, нечесність, заздрісність, скупість, неврівноваженість, дратівливість, невпевненість у собі, образливість, надмірну педантичність, відсутність почуття гумору, завищену самооцінку тощо. Усе це робить неефективною таку важливу педагогічну зброю учителя, як його особистий приклад.

За дорученням Міністерства освіти і науки України вчені Інституту проблем виховання НАПН України за участю наукових працівників Державної наукової установи «Інститут модернізації освіти» під керівництвом академіка, доктора психологічних наук Івана Дмитровича Беха розробили Програму «Нова українська школа» у поступі до цінностей, яка допоможе вчителеві, класному керівнику, вихователю, адміністрації закладів освіти осмислити сучасні виклики виховання та його головні засади, базові моральні цінності сучасного виховання 3 обов'язковим урахуванням вікових особливостей учнів. 
Складність сучасних виховних проблем потребує комплексного підходу в їх розв'язанні та розвитку соціально-педагогічної парадигми виховання. Основою нової парадигми, а отже, й основою виховання є особистість дитини, визнання ii найвищою цінністю, орієнтація педагога на гуманні, демократичні принципи спільної 3 дитиною життєдіяльності, тобто генерація стратегії суб'єкт-суб'єктної взаємодії.

Нова парадигма виховання полягає в розумінні дитини як суб'єкта і мети виховання, орієнтує на усвідомлення виховання як соціально-педагогічного явища, на підвищення виховного потенціалу освітнього середовища та проєктування цілісного виховного простору. Серед превентивних заходів у роботі 3 дітьми першочерговими вважаємо такі:

- приділення особливої уваги формуванню ідентичності, основ духовності особистості, культури мислення і культури поведінки, профілактиці шкідливих звичок, ризикованої, девіантної і кримінальної поведінки, жорстокості і насилля в учнівському середовищі, різних видів залежностей;

- бачення реальних та потенційних можливостей вихованців, уміння оцінити та передбачити їх, визначення оптимальних шляхів і методів для забезпечення реалізації успішної діяльності вихованців (створення необхідних умов для навчально-пізнавальної діяльності учнів, гармонійного виховання та розвитку, змістовного відпочинку і дозвілля, самореалізації, набуття навичок здорового способу життя; уміння позитивно стимулювати творчу активність учнів; розробляти індивідуально-орієнтовані освітні проєкти);

- відчуття творчого світогляду дитини через психологічну спостережливість, уміння проникати у внутрішній світ учня, глибоко розуміти особистість, iii тимчасові психічні стани (зокрема за незначними «дрібницями» бачити зміни у внутрішньому стані вихованця, будувати індивідуалізовану освітню програму, показати особистісне розуміння навчання з урахуванням індивідуальних характеристик).

Найважливішою специфічною особливістю педагогічної праці, яка породжує труднощі у виховній роботі, є подвійний характер об'єкта виховання - учня. 3 одного боку, він є об'єктом педагогічних зусиль, ефективність яких значною мірою визначає успіх виховання. У педагогічному середовищі поширені висловлювання: «Дитина - це чистий аркуш паперу», «Дитина - це глина», які наголошують на відповідальності педагога за результати виховання. Ця відповідальність є однією з найважливіших вимог педагогічного кодексу.

3 іншого боку, дитина є суб'єктом власного розвитку, тобто формується відповідно до своїх потреб. Починаючи не досить чітко усвідомлювати ці потреби в ранньому дитинстві, людина з віком усе менше піддається впливу, який йде всупереч їі інтересам та бажанням. Для забезпечення ефективного педагогічного впливу у вихованців необхідно формувати мотиви необхідної поведінки, тобто уникати ситуацій суперечності педагогічних вимог потребам та переконанням учнів. У повсякденній практиці педагоги часом забувають цю істину і не дуже турбуються про формування мотивації учнів до доцільної поведінки. Те, що їх вимоги загалом спрямовані на користь учнів, видається їм достатньою основою для прямолінійної вимогливості та нехтування «нюансами». Інша специфічна особливість педагогічної праці полягає в тому, що виконавець та інструмент педагогічної праці це одне й те ж - особистість педагога.

Розвиток науки і техніки дає педагогам нові форми комунікацій, типи розв'язання абстрактних i конкретних завдань, перетворюють учителя з авторитарного транслятора готових ідей у натхненника розвитку інтелектуального і творчого потенціалу дитини, тому потреба в педагогах високої кваліфікації за умов постійних змін у суспільстві $є$ одним із найактуальніших питань.

Реформування освіти передбачає розвиток інноваційних перетворень у різних сферах життєдіяльності людини, набуття компетентностей особистістю задля підвищення конкурентоздатності, інтеграцію у світовий освітній простір. «Однак компетентності, як зазначає О. Савченко, - складно формувати, а ще складніше вимірювати, але без цього якісна шкільна освіта у XXI столітті неможлива» [6].

Педагог має справу з конкретними людьми: дітьми свого класу, школи, іншого закладу, проте його завдання не лише особистісно, а й суспільно зумовлене: підготовка підростаючого покоління до активної участі в житті суспільства. Призначення вчителя бути ланкою в передаванні суспільного досвіду, сприяти соціальному прогресові.

На вчителя покладено соціальну відповідальність за наслідки його праці. Особливо значущою $є$ місія вчителя в наш час, коли досить виразно спостерігається небезпечний для долі цивілізації розрив між технічною підготовкою людини і рівнем її соціальної свідомості, моральності. Усе це потребує підвищення культури народу, а отже, гуманізації освіти.

Концепція Нової української школи пропонує виховний компонент змісту компетентностей, визначених у Законі України «Про освіту». Закладені основні орієнтири компетентнісного виховання особистості учня можуть творчо наповнюватися конкретним змістом з урахуванням особливостей функціонування закладу освіти, вікових та індивідуальних можливостей учнів, інших актуальних соціальних викликів.

Як зазначає I. Д. Бех, проблемами, які потребують свого вирішення у вихованні, $є$ :

- втрата смисложиттєвих дороговказів значною частиною старших поколінь, а отже, унеможливлення передачі позитивного соціального досвіду дітям та онукам;

- девальвація виховної функції школи на фоні поширення ставлення до школи як «освітньої послуги»; зниження цінності виховання в педагогічній свідомості;

- невідповідність, неадекватність змісту, форм, методів і засобів виховання новітнім умовам дорослішання підростаючої особистості;

- дефіцит форм, методів, технологій виховної роботи щодо формування культури вибору світоглядних, моральних зразків, формування соціокультурної ідентичності учнів, потенціалу громадянської дії у дітей та молоді; 
- відсутність системності та цілісності у вихованні учнів, фрагментарність наступності в організації виховної діяльності в закладах освіти;

- диктатний, авторитарний характер стосунків між учителями і дітьми, домінування вербальних методів виховання;

- стигматизація мислення фахівців, які здійснюють виховну діяльність, їх відданість моралізаторським, «залякуючим», «ізоляційним» методам і підходам;

- методична i технологічна непідготовленість педагогічних працівників до здійснення інновацій; некоректне впровадження соціально-педагогічних технологій;

- низький рівень розвитку психолого-педагогічної компетентності частини вчителів у зв'язку з відсутністю в закладах освіти системної методичної роботи з питань виховання;

- різновекторність виховних впливів і неузгодженість дій різних суб'єктів виховання (сім'ї, дитячих і молодіжних об'єднань, закладів позашкільної освіти, закладів культури, спорту, охорони здоров'я тощо) у створенні виховного середовища;

- низький рівень розвитку інфраструктури виховного процесу в школах, дефіцит ресурсного забезпечення;

- недосконалість системи моніторингу виховання, необгрунтованість критеріїв, показників, інструментарію оцінювання виховних результатів, переважання кількісної фіксації результатів виховання на противагу (на шкоду) їх якісному аналізу [1].

Акцентуючи увагу на ролі вчителя у формуванні особистості дитини, Н. Ничкало зазначає: «Від часів античності добре відома, здавалося б, дуже проста істина: у розвитку освіти на різних історичних етапах завжди був і нині є ключовою фігурою саме Вчитель» $[4$, c. 5$]$.

Ключовим завданням педагога $є$ виховання людини, здатної не втратити найбільш важливі морально-етичні цінності суспільного співіснування. Адже морально-етичні, естетичні цінності нині відіграють найважливішу роль як у соціальному, так і в особистісному житті, утворюючи основу всіх видів соціальної діяльності, своєрідне «ядро» особистісної визначеності людини, зумовлюючи піi соціальні властивості та риси [2, с. 14].

Отже, як ми зазначали вище, метою професійної діяльності педагога як вихователя і носія цінностей $\epsilon$ створення умов для всебічного гармонійного розвитку особистості учня, його самореалізації, розкриття індивідуальності, творчого потенціалу. Вчитель має усвідомлювати унікальність і неповторність учня як індивідуальності, зважати на складність і неоднозначність процесу його становлення, свою відповідальність як фахівця. Талант вихователя - це яскраві здібності організатора, логічне мислення, вміння спілкуватися, переконувати і навіювати, прагнення до нових знань та ерудиція, інтерес до нових педагогічних ідей, відсутність догматизму, особиста порядність, уміння володіти собою. Водночас талант учителя, вихователя виявляється по-різному залежно від того, які здібності й особистісні риси переважають у педагога.
Учитель XXI століття - це той, хто насамперед уміє знаходити спільну мову зі своїми учнями. Тобто він має бути ідеальним психологом. Крім того, вчитель повинен йти в ногу з часом, бути різнобічною людиною та не обмежуватися лише сферою свого предмета.

Висновки. Отже, сучасний учитель повинен бути не лише вимогливим і суворим викладачем та досконало знати свій предмет, а й насамперед професіоналом-ерудитом, помічником, порадником і другом своїх учнів, сучасною інтелігентною людиною, якій під силу опанувати нові технології, легко адаптуватися до змін і вміти навчатися впродовж усього життя. Лише такий учитель зможе зрозуміти своїх «нових» учнів і буде їм цікавий. Він допомагатиме і підтримуватиме працю дитини, стимулюватиме іiі творчі ідеї та готуватиме до динамічного життя, щоб у майбутньому вона стала самостійною, творчою, впевненою у собі особистістю!

Саме за таких умов значення вчительської професії ніхто не зможе піддати сумніву: «Тисячі професій народжуються і вмирають, та серед вічних професій учительська посідає особливе місце: вона - початок усіх професій. Змінюються умови й засоби виховання, та незмінним залишається головне призначення вчителя - навчити людину бути Людиною» (за І. Зязюном) [5].

\section{СПИСОК ВИКОРИСТАНОЇ ЛІТЕРАТУРИ}

1. Бех І. Концепція виховання гуманістичних цінностей учнів загальноосвітньої школи / І. Бех, Н. Ганнусенко, К. Чорна // Українське релігієзнавство. 2005. - № 36. - C. 265-281. URL: http://nbuv.gov.ua/ UJRN/Ukrr_2005_4_51 (дата звернення: 20.12.2019).

2. Дзвінчук Д. І. Освіта як пріоритетна суспільна цінність / Д. І. Дзвінчук, О. В. Краснікова // Наук. часопис Нац. пед. ун-ту ім. М. Драгоманова. - К. : Видво НПУ ім. М. Драгоманова, 2012. - Вип. 29 (42). С. 14-18. - (Серія 7 «Релігієзнавство. Культурологія. Філософія»).

3. Концепція Нової української школи / Міністерство освіти і науки України. URL: mon.gov.ua (ua) (дата звернення: 14.08.2019).

4. Ничкало Н. Г. Педагогічна майстерність - крила в майбутнє / Н. Г. Ничкало // Педагогічна майстерність : підручник / І. А. Зязюн, Л. В. Крамущенко, І. Ф. Кривонос та ін. ; за ред. І. А. Зязюна. - Вид. 3., допов. і перероб. - К. : СПД Богданова А. М., 2008. C. 5-8.

5. Педагогічна майстерність : підручник / І. А. Зязюн, Л. В. Крамущенко, І. Ф. Кривонос та ін. ; за ред. I. А. Зязюна. - К. : Вища школа, 1997.

6. Савченко О. Я. Досвід реформування української освіти: уроки і подальший поступ / О. Я. Савченко // Шлях освіти. - 2010. - № 3. - С. 2-6.

7. Формула Нової української школи - структура НУШ. Практика управління дошкільним закладом. URL: https://www.pedrada.com.ua/article/1296-qqq17-m5-16-05-2017-do-chogo-vede-formula-novoukransko-shkoli (дата звернення: 18.02.2020).

Дата надходження до редакиї: 26.02.2020 p. 